\title{
BUILDING THE "KANSAS CITY CUT OFF"*
}

\author{
By GEO. M. TITUS
}

As I approach the sunset of life, I like to dwell on the high spots of my experience. The other day I received from an official of the Chicago, Milwaukee \& St. Paul railroad a request that I outline for them the history of the inception and building of their line known as the "Kansas City Cut Off." It constitutes the direct, line extending from Muscatine through Washington to Ottumwa. In the preparation of a general history of their road they desired to secure details as to the building of their particular trackage from the one whose brain child it was, and who personally secured for the enterprise the right.of-way and town sites in Muscatine county.

If a recital of these events has importance as a part of the history of the Milwaukee road in Iowa, I was proud to comply with their request. And it occurs to me that it might have value in the files of the Iowa State Department of History, so that in the future anyone desiring to investigate the history of railroads in Iowa might have access to this information. Besides, quite naturally, I want the record to show that I had something to do with the early development of the state's transportation facilities. This is the story, as I have written it for L. A. Summers, agent of the Milwaukee road at Ardon, Iowa.

In 1886 I was the secretary of the Chamber of Commerce of Muscatine. I had an ambition to have something accomplished for the city while I occupied that office. I inspected the map to see what we could do to get another railroad into Muscatine. We had only the Rock Island line. After looking at the map for some time, I decided that the Milwaukee road was the most available.

* A manuscript in the files of the Iowa State Department of History and Archives dictated in March 1946 by the late Sen. Geo. M. Titus of Muscatine. 
Thereupon I wrote to Roswell Miller, then manager of the Milwaukee road, on the stationery of the Chamber of Commerce, or Board of Trade, as it was then called. I wrote a two and a half-page letter with pen (we had no typewriters then) suggesting that his company consider the matter of building a railroad from Ottumwa to Muscatine on an airline between the Rock Island lines with the Montezuma line on the north and the Kansas City line on the south.

I stated that rapid transportation was the order of the day, and I knew that their line then extended from Ottumwa to Cedar Rapids, Marion and on to Chicago from that point. The air line suggested, in my judgment, would save at least four hours in moving freight from Kansas City to Chicago, and a like saving of time with passenger traffic.

I had no acquaintance with $\mathrm{Mr}$. Miller and did not know whether my letter would receive any attention. To my surprise, in about ten days I received a reply from Mr. Miller stating that my letter was read at the board meeting of their company and was favorably considered. He said he would write me further when the matter had received full attention.

I had another communication from Roswell Miller, the manager, stating that the Board had acted favorably on my suggestion and were considering the extension of their line to the Pacific coast, and that he would like to have their manager of construction visit Muscatine, but did not care to have any publicity about it. I replied that I would be glad to entertain the representative of their company at my home and no publicity would be had. In due course of time a $\mathrm{Mr}$. Kimball as a representative of the Milwaukee company came to Muscatine and I entertained him at my home. From this point he went on to Ottumwa and I suppose investigated intervening points. When he left me he said he would, if he was allowed to, make a report to me as to the ac- 
tion of the board on what he might report. In due course, I received a letter from $\mathrm{Mr}$. Kimball that the board considered his report favorably.

\section{COMPANY ENGINEER ON JOB}

Later on a Mr. Baker, engineer for the company, came to my office and said he was out as a scout for the company for a line from Muscatine to Ottumwa, and his investigation showed that the Rock Island road passed through Whiskey Hollow, which constituted the best line through the hills that skirted Muscatine Island. I told him that I had considered that matter and that in my judgment the only thing for them to do was to plan a line equally distant from the Montezuma-Rock Island line and the Kansas City-Rock Island line, and climb the bluffs west of Muscatine in the easiest possible approach. He returned to my office in a few days and said that I was right; that this was the only feasible plan, but it made necessary a ninty-foot fill on the Adam Wigim farm, which would be the deepest fill the company had up to that date upon its entire system.

Later on Mr. Edwards, the company secretary, came to Muscatine and said that they wanted to get options on the right-of-way from Muscatine to Ottumwa as soon as possible. He asked if I would be willing to undertake to secure options for the right-of-way through Muscatine county, and what I would charge, I replied if he wanted someone to get the right-of-way-by "skinning" the farmers on the line I did not care to undertake it, but if he was willing to treat the farmers fairly I would undertake the job for $\$ 1,000.00$ compensation. He said that he wanted the farmers to be treated fairly and a good taste left after the right-of-way was acquired; but he said, "I feel that you can do it in one month and your price is a little high." I responded, "I know what the estimate of Mr. Baker is for the right-of-way across this county and I would be willing to take half of what I can save you under his estimate and still deal fairly with the farmers." He said, "Ordinarily that would be a 
good proposition, but being a corporation they might be accused of unfair dealing." I then said to him "You accept my proposition of $\$ 1,000.00$, and when I have finished, if you think that is too high, you can scale it down to whatever point you think is fair, as I am anxious to get in touch with railroad men."

Only one condemnation suit was had. That was on Jim Healey's farm where he wanted twice what I offered him, which was $\$ 5,000.00$. The condemnation jury allowed him $\$ 5,150.00$ as against the $\$ 10,000.00$ he had asked. The Milwaukee railroad paid me $\$ 1,250.00$ when the work was completed.

\section{ESTABLISHING THE STATIONS}

When it came to establishing stations, the people of Seventy-six township thought there should be only one station between Muscatine and Cone. I agreed with them, but when called to the main office in Chicago, Mr. Earling, then president, agreed with me that one station between Muscatine and Cone would become a larger town than either of two stations; but he said "We have only one track and the passing of freight trains is an important thing. The distance between Muscatine and one town in Seventy-six township would be too great. Therefore, it is necessary to have two stations."

Then Mr. Earling indicated to me on the blue print where the stations should be, and said they would have to have at least twenty acres at each point. He asked that I or Titus \& Jackson should do the best we could in getting the farmers owning this ground to give them the land, with the right to do anything we cared to about laying out a town and selling lots. They would not let the general public know where the stations were to be and authorized us to get any option we wishd and they did not care what we made out of the operation.

\section{FARMERS Protested Station LOCATions}

Later on a committee from Seventy-six township went to Chicago at an appointed time to meet Mr. Earling, to whom they said, "That man Titus is working against 
the interests of our community and we think against your company; they, of course, not then knowing that I was limited to the two particular points. I understood that Mr. Earling told them they had perfect confidence in me and whatever I decided on the matter would be followed by the company, purposely not disclosing that he had given me exact directions where the stations should be located. That resulted in the station named Ardon, and the next station was then named Madura. We arranged with Frank Fry for twenty or thirty acres, I do not recall just which, and laid out the town of Madura. The name of that station was changed to Cranston, because Madura was too much like the name of another station. We succeeded in selling all the lots of Madura, giving to Mr. Fry his original price on the land and dividing the balance fifty-fifty.

I suggested that the Milwaukee build a bridge at Muscatine to cross the river at this point and follow up to Rock Island, where they would intercept the Chicago line. While visting in Mr. Earling's office he told me that they had made arrangement with the Rock Island company to use their line from Muscatine to Rock Island, and in turn they would give the Rock Island the use of the Milwaukee into St. Paul, and he showed me the agreement, which I did not take the time to read. This he said would not necessitate the bridging of the river at Muscatine. I am told, however, that the Milwaukee company regretted not following the original plan and building a bridge over the Mississippi at Muscatine, thereby reaching the coal fields of Illinois.

In naming the stations on the "Kansas City Cut Off," Mr. Edwards, while in Muscatine, said to me: "Mr. Titus, we have complimented you as the originator of this project by naming one of our stations after you. The first station west of Washington we have called 'Titus," " and he said, "It may build up and be quite a town, and some day you can give them a library." This station, however, only six miles from Washington, is 
no longer maintained except as a passing and loading point.

I remember with a good deal of pleasure meeting the president, Mr. Earling, the secretary, Mr. Edwards, and Mr. Laas, manager of construction, with whom I became quite well acquainted, and the latter also became a client of our office. I am still having correspondence with his son, Robert Laas, of Chicago, the father having passed away several years ago.

Much more could be written upon the story of the Milwaukee road, but I fancy that this is all that will be needed and I am well pleased to have the present officers of the company know of my connection with the proposition. If I live until the 19th of next May I will celebrate my ninetieth birthday. One of the highlights of my experience in life is my connection with the Milwaukee road during its construction of the "Kansas City Cut Off."

\section{THE LEGAL INSTITUTE PROGRAM}

\section{By JUdGE J. E. HeisermaN}

Any history of the Legal Institute Program in Iowa should begin with mention of the Lawyers' Chautauqua. For many years the lawyers of the Fourteenth and Twenty-first judicial districts of Iowa banded together their talents and energies, and each summer have held at Lake Okoboji, a series of lectures and discussions upon various legal subjects, covering a period of several days. By the year 1938, this annual meeting had come to be known as the Lawyers' Chautauqua. Due to its success and favorable mention among lawyers throughout the state, undoubtedly it was the forerunner of the Legal Institute Program.

The movement to incorporate a state-wide Legal Institute Program as part of the activities of the Iowa State Bar association first took definite form during the tenure of Burt J. Thompson, of Forest City, as president 
Copyright of Annals of Iowa is the property of State of Iowa, by \& through the State Historical Society of Iowa and its content may not be copied or emailed to multiple sites or posted to a listserv without the copyright holder's express written permission. However, users may print, download, or email articles for individual use. 